\title{
Faktor risiko kegagalan pemberian asi eksklusif di Kabupaten Bantul
}

\author{
Risk factors of failure to exclusive assessment in Bantul district

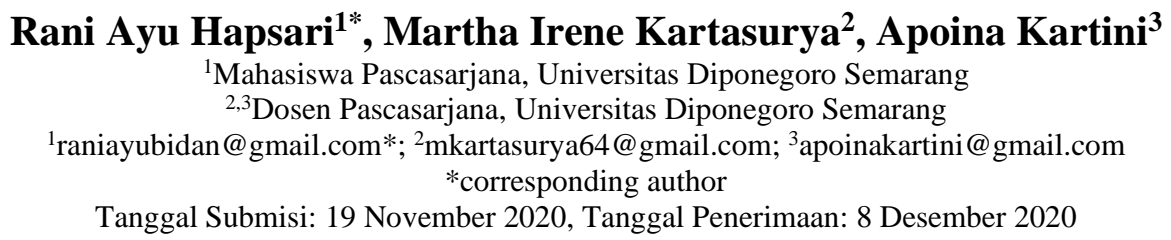

\begin{abstract}
Abstrak
Pada tahun 2018, keberhasilan ASI eksklusif di Indonesia sebesar 61,33\%, DIY sebesar 74,9\% pada 2017 dan Bantul sebesar 74,27\% pada tahun 2017. Tujuan penelitian adalah untuk menganalisis faktor risiko kegagalan pemberian ASI eksklusif. Jenis penelitian observasi analitik, dengan desain case kontrol. Analisis data menggunakan regresi logistic. Hasilnya menunjukkan variable yang bukan merupakan faktor risiko kegagalan ASI eksklusif adalah pelaksanaan IMD, pengetahuan dan dukungan keluarga. Faktor risiko kegagalan ASI eksklusif adalah keikutsertaan Kelas Ibu Hamil, keikutsertaan KP ibu dan dukungan suami. Kata Kunci: ASI eksklusif; factor risiko; kegagalan
\end{abstract}

\begin{abstract}
In 2018, the success of exclusive breastfeeding in Indonesia was $61.33 \%$, DIY was 74.9\% in 2017 and Bantul was 74.27\% in 2017. The aim of the study was to analyze the risk factors for failure of exclusive breastfeeding. This type of analytic observation research, with a case control design. Data analysis using logistic regression. The results show that the variables that are not a risk factor for the failure of exclusive breastfeeding are the implementation of IMD, knowledge and family support. Risk factors for failure of exclusive breastfeeding are participation in pregnant women classes, participation in maternal KP and support from husbands.
\end{abstract}

Keywords: exclusive breastfeeding; failure; risk factors

\section{PENDAHULUAN}

Berdasarkan data Kementerian Kesehatan (Kemenkes) tahun 2018 keberhasilan pemberian ASI eksklusif Indonesia sebesar 61,33\% (Kemenkes 2018).. Keberhasilan ASI eksklusif tahun 2017 di DIY sebesar 74,9\%. Keduanya lebih kecil dari target nasional (80\%) namun lebih besar dari target Renstra 2017 (44\%) (Dinkes 2017). Cakupan ASI Eksklusif Bantul pada 2017 masih 74,27\% lebih kecil dari tahun 2016 (75,06\%). Angka Kematian Bayi (AKB) 2017 sebesar 8,74/1.000 kelahiran hidup lebih tinggi dari 2016 sebanyak 7,65/1.000 kelahiran hidup (Bantul 2020).

Keberhasilan pemberian ASI eksklusif dipengaruhi oleh 3 faktor utama yaitu predisposing factors (factor pemudah), enabling factors (factor pendukung) 
dan reinforcing factors (factor pendorong). Contoh predisposing factors adalah pengetahuan, pendidikan, persiapan ASI eksklusif pada masa kehamilan dan adat budaya. Contoh factor pendukung adalah kesehatan ibu, ketersediaan waktu dan pendapatan keluarga. Contoh reinforcing factors adalah dukungan petugas kesehatan dan dukungan keluarga (Setianingsih 2014). Hasil penelitian membuktikan bahwa pengetahuan adalah factor dominan yang berhubungan dengan keberhasilan pemberian ASI eksklusif (72,8\%). Factor lain yang berhubungan adalah sikap positif $(72,1 \%)$, dukungan keluarga $(75,7 \%)$, dukungan atasan $(65,9 \%)$ dan dukungan teman kerja $(68,8 \%)$ (Septiani 2017). Penelitian menyebutkan sosial ekonomi, dukungan keluarga, meniru teman dan sikap adalah faktor yang mempengaruhi keberhasilan ASI eksklusif. Sosial ekonomi adalah factor determinan yang mempengaruhi keberhasilan ASI eksklusif (Kurniawati\&Rachmat 2014). Penelitian lain menyebutkan bahwa setiap bulan keluarga, dukungan suami dan kepercayaan ibu terhadap produksi ASI berpengaruh terhadap. Pada bulan ketiga dan keempat, status pekerjaan ibu mempengaruhi keberhasilan pemberian ASI eksklusif (Dwinanda 2018).

Hasil studi pendahuluan didapatkan informasi bahwa dari $11 \mathrm{ibu}$ menyusui, 7 (63,6\%) diantaranya tidak memberikan ASI eksklusif pada bayinya dan hanya 4 orang $(36,4 \%)$ yang memberikan ASI eksklusif pada bayinya. Penelitian ini bertujuan untuk menganalisis faktor risiko kegagalan pemberian ASI eksklusif di Yogyakarta

\section{METODE}

Jenis penelitian observasi analitik, dengan desain case kontrol. Pendekatan waktu yang digunakan adalah case kontrol. Metode pengumpulan data menggunakan data kuantitatif. Populasi penelitian adalah ibu menyusui berjumlah 195 orang di wilayah kerja Puskesmas Bantul 1 Kabupaten Bantul. Teknik pengambilan sampel dalam penelitian ini menggunakan teknik non probability sampling dengan purposive sampling didapatkan sampel minimal yang akan diperlukan dalam penelitian ini sebanyak 168 orang, dimana dibagi menjadi 2 masing-masing 84 orang untuk kelompok kasus dan 84 orang untuk kelompok kontrol. Instrumen pengumpul data menggunakan kuesioner yang telah diuji validitas dan reliabilitasnya. Analisis data menggunakan regresi logistic.

\section{HASIL PENELITIAN DAN PEMBAHASAN}

\section{Karakteristik responden}

Karakteristik responden penelitian dapat diperlihatkan pada tabel berikut:

Tabel 1. Distribusi Frekuensi Karakteristik Responden

\begin{tabular}{|c|c|c|c|c|c|c|}
\hline \multirow[t]{2}{*}{ No. } & \multirow{2}{*}{$\begin{array}{c}\text { Karakteristik } \\
\text { Responden }\end{array}$} & \multicolumn{2}{|c|}{ Gagal ASI eksklusif } & \multicolumn{2}{|c|}{ Berhasil ASI eksklusif } & \multirow[t]{2}{*}{$\mathbf{P}$} \\
\hline & & Frekuensi (f) & $\begin{array}{c}\text { Persentase } \\
(\%)\end{array}$ & Frekuensi (f) & $\begin{array}{c}\text { Persentase } \\
(\%)\end{array}$ & \\
\hline \multirow[t]{3}{*}{1} & Pekerjaan & & & & & \\
\hline & a. Bekerja & 57 & 83,9 & 64 & 88,1 & \multirow{2}{*}{$0,123^{*}$} \\
\hline & b. Tidak bekerja & 27 & 16,1 & 20 & 11,9 & \\
\hline \multirow[t]{2}{*}{2.} & Urutan anak & & & & & \\
\hline & $\begin{array}{ll}\text { a. } & \text { Anak } \\
\text { pertama }\end{array}$ & 31 & 18,5 & 12 & 7,1 & $0,003 *$ \\
\hline
\end{tabular}




\begin{tabular}{|c|c|c|c|c|c|c|}
\hline \multirow[t]{2}{*}{ No. } & \multirow{2}{*}{$\begin{array}{c}\text { Karakteristik } \\
\text { Responden }\end{array}$} & \multicolumn{2}{|c|}{ Gagal ASI eksklusif } & \multicolumn{2}{|c|}{ Berhasil ASI eksklusif } & \multirow[t]{5}{*}{$\mathbf{P}$} \\
\hline & & Frekuensi (f) & $\begin{array}{c}\text { Persentase } \\
(\%)\end{array}$ & Frekuensi (f) & $\begin{array}{c}\text { Persentase } \\
(\%)\end{array}$ & \\
\hline & b. Anak Kedua & 34 & 20,2 & 42 & 25 & \\
\hline & c. Anak Ketiga & 12 & 7,1 & 25 & 14,9 & \\
\hline & $\begin{array}{ll}\text { d. } & \begin{array}{l}\text { Anak } \\
\text { keempat }\end{array} \\
\end{array}$ & 7 & 4,2 & 5 & 3 & \\
\hline \multirow[t]{3}{*}{3} & Jenis persalinan & & & & & \\
\hline & a. Normal & 65 & 79,2 & 58 & 69,8 & \multirow[t]{2}{*}{$0,228^{*}$} \\
\hline & b. Tidak normal & 19 & 20,8 & 26 & 30,2 & \\
\hline \multirow[t]{2}{*}{4.} & Penghasilan keluar & alam sebulan & & & & \\
\hline & Beda rata-rata & & \multicolumn{2}{|c|}{478325.29} & & $\begin{array}{c}0,039 \\
* *\end{array}$ \\
\hline \multirow[t]{2}{*}{5.} & Berat Badan Lahir & & & & & \\
\hline & Beda rata-rata & & \multicolumn{2}{|c|}{58.51} & & $\begin{array}{c}0.355 * \\
*\end{array}$ \\
\hline
\end{tabular}

*Uji statistic menggunakan chi square

**Uji statistic menggunakan uji beda

Tabel 1. menunjukkan faktor risiko yang tidak ada hubungannya dengan kegagalan pemberian ASI eksklusif adalah pekerjaan, jenis persalinan dan BBL. Factor risiko yang ada hubungannya dengan kegagalan pemberian ASI eksklusif adalah urutan anak dan penghasilan keluarga. Hasil studi menyebutan ada hubungan keberhasilan pemberian ASI eksklusif pada bayi usia 0-6 bulan dengan paritas (Wadud 2012). Paritas merupakan jarak kelahiran hidup secara berurutan yang dialami oleh seorang wanita. Anak yang lahir terakhir dengan jarak kelahiran lebih dari 1 tahun sebagian besar tidak diberikan ASI eksklusif oleh ibunya $(67,5 \%)(B K K B N 2011)$. berikut:

Gambaran lama pendidikan responden dapat diperlihatkan pada table 2

Tabel 2. Distribusi Frekuensi Lama Pendidikan Kelompok Kasus dan Kelompok Control

\begin{tabular}{|c|c|c|c|c|c|c|c|c|}
\hline \multirow[t]{3}{*}{ No. } & \multirow{3}{*}{$\begin{array}{c}\text { Lama pendidikan } \\
\text { (tahun) }\end{array}$} & \multicolumn{4}{|c|}{ Pemberian ASI eksklusif } & & & \\
\hline & & \multicolumn{2}{|c|}{$\begin{array}{c}\text { Kelompok } \\
\text { kasus }\end{array}$} & \multicolumn{2}{|c|}{$\begin{array}{c}\text { Kelompok } \\
\text { kontrol }\end{array}$} & & & \\
\hline & & $\mathbf{F}$ & $\%$ & $\mathbf{F}$ & $\%$ & $\mathbf{X}$ & $\mathbf{p}$ & $\overline{\text { OR }}$ \\
\hline 1. & Sebentar $(<9$ tahun $)$ & 6 & 5,4 & 9 & 8,9 & \multirow[t]{3}{*}{1.067} & \multirow[t]{3}{*}{0,238} & \multirow[t]{3}{*}{0,471} \\
\hline 2. & Lama (> 9 tahun) & 78 & 94,6 & 75 & 91,1 & & & \\
\hline & Total & 84 & 100 & 84 & 100 & & & \\
\hline
\end{tabular}

Tabel 2. menunjukkan bahwa $94,6 \%$ responden yang mengalami kegagalan ASI eksklusif pemberian dan berhasil memberikan ASI eksklusif 92,2\% dengan lama pendidikan lebih dari 9 tahun. Hasil uji di square didapatkan tidak ada perbedaan lama pendidikan kelompok kasus dan kelompok kontrol untuk mengalami kegagalan ASI eksklusif. Kegagalan dalam memberikan ASI eksklusif dapat dialami oleh responden dengan lama pendidikan kurang dari 9 tahun maupun yang lebih dari 9 tahun.

Lama pendidikan seseorang tidak memberikan jaminan terjadinya perubahan perilaku dalam hal pemberian ASI eksklusif. Penelitian ini membuktikan bahwa responden dengan lama pendidikan kurang dari 9 tahun dan lebih dari 9 tahun mempunyai peluang yang sama untuk mengalami kegagalan dalam memberikan ASI eksklusif pada bayinya. penelitian ini tidak sesuai dengan 
penelitian yang menyebutkan bahwa keberhasilan pemberian ASI eksklusif dipengaruhi oleh pendidikan dan pengetahuan (Suwardiman 2015). Penelitian lain yang tidak sesuai adalah penelitian Ida yang membuktikan bahwa ibu dengan pendidikan lebih tinggi mempunyai peluang 5,2 kali lebih besar untuk berhasil dalam memberikan ASI eksklusif dibandingkan ibu yang berpendidikan rendah (Ida 2012).

Gambaran Pelaksanaan IMD responden dapat diperlihatkan pada table 3 berikut:

Tabel 3. Distribusi Frekuensi Pelaksanaan IMD kelompok kasus dan kelompok control

\begin{tabular}{c|l|c|c|c|c|c|c|c}
\multirow{2}{*}{ No. } & Pelaksanaan & \multicolumn{2}{|c|}{ Kelompok kasus } & \multicolumn{2}{|c|}{ Kelompok kontrol } & \multicolumn{2}{|c}{} \\
\cline { 3 - 7 } & IMD & $\mathbf{F}$ & $\mathbf{\%}$ & $\mathbf{F}$ & $\mathbf{\%}$ & $\mathbf{X}$ & $\mathbf{p}$ & OR \\
\hline 1. & Tidak & 25 & 28 & 17 & 20,8 & 0.545 & 0,274 & 1,4 \\
\hline 2. & Ya & 69 & 72 & 67 & 79,2 & & & \\
\hline & Total & 84 & 100 & 84 & 100 & & &
\end{tabular}

Uji statistic menggunakan chi square

Tabel 3. menunjukkan bahwa responden yang dapat melakukan IMD 72\% mengalami kegagalan pemberian ASI eksklusif dan 79,2\% berhasil memberikan ASI eksklusif. Hasil uji chi square disimpulkan tidak ada perbedaan pelaksanaan IMD antara kelompok kasus dan kelompok kontrol dalam mengalami kegagalan ASI eksklusif. Kegagalan dalam memberikan ASI eksklusif dapat dialami oleh ibu yang melaksanakan IMD maupun yang tidak melaksanakan IMD.

Ibu yang gagal memberikan ASI eksklusif meskipun telah melaksanakan IMD selama 60 menit (1 jam) dikarenakan ASI tidak lancar meskipun telah dirangsang dengan IMD. Ketidaklancaran ASI dapat disebabkan karena perawatan payudara yang tidak benar selama masa kehamilan sehingga meskipun diberikan rangsangan melalui IMD, ASI tetap tidak keluar seperti yang diharapkan. Selain itu ketidaklancaran ASI dikarenakan bayi tidak melekat sempurna pada payudara ibu yang menyebabkan hisapan bayi pada puting kurang kuat untuk mengeluarkan ASI. Kondisi ini menyebabkan ASI yang keluar lebih sedikit. Selain itu, stimulasi dan rangsangan tubuh untuk memproduksi ASI juga menurun. Bayi yang melekat tidak sempurna pada payudara ibu sering disebabkan karena posisi menyusui yang tidak tepat. Produksi ASI juga berkurang atau tidak lancar karena keterbatan frekuensi dan waktu menyusui (Setyowati 2018).

Gambaran Keikutsertaan Kelas Ibu Hamil responden dapat diperlihatkan pada table 4 berikut:

Tabel 4. Distribusi Frekuensi Keikutsertaan Kelas Ibu Hamil Kelompok Kasus dan Kelompok Control

\begin{tabular}{|c|c|c|c|c|c|c|c|c|}
\hline \multirow[t]{2}{*}{ No. } & \multirow{2}{*}{$\begin{array}{c}\text { Keikutsertaan } \\
\text { Kelas Ibu } \\
\text { Hamil } \\
\end{array}$} & \multicolumn{2}{|c|}{$\begin{array}{c}\text { Kelompok } \\
\text { kasus }\end{array}$} & \multicolumn{2}{|c|}{$\begin{array}{c}\text { Kelompok } \\
\text { kontrol }\end{array}$} & \multirow[b]{2}{*}{$\mathbf{X}$} & \multirow[b]{2}{*}{ p } & \multirow[b]{2}{*}{ OR } \\
\hline & & $\mathbf{F}$ & $\%$ & $\mathbf{F}$ & $\%$ & & & \\
\hline 1. & $\mathrm{Ya}$ & 64 & 75,0 & 74 & 87,5 & \multirow[t]{3}{*}{4.573} & \multirow[t]{3}{*}{0,025} & \multirow[t]{3}{*}{2.35} \\
\hline 2. & Tidak & 20 & 25,0 & 10 & 12,5 & & & \\
\hline & Total & 84 & 100 & 84 & 100 & & & \\
\hline
\end{tabular}

Uji statistic menggunakan chi square

Berdasarkan tabel 4. menunjukkan bahwa kegagalan pemberian ASI eksklusif yang dialami responden yang ikut serta KIH sebanyak $74,4 \%$. Responden yang ikut KIH dan berhasil memberikan ASI eksklusif 86,9\%. Hasil 
uji chi square menyimpulkan ada perbedaan kegagalan ASI eksklusif antara ibu yang ikut Kelas Ibu Hamil (KIH) dan yang tidak ikut KIH. Responden yang tidak ikut KIH berpeluang 2.35 kali lebih besar untuk mengalami kegagalan dalam memberikan ASI eksklusif.

Ibu yang gagal memberikan ASI eksklusif meskipun telah melaksanakan IMD selama 60 menit (1 jam) dikarenakan ASI tidak lancar meskipun telah dirangsang dengan IMD. Ketidaklancaran ASI dapat disebabkan karena perawatan payudara yang tidak benar selama masa kehamilan sehingga meskipun diberikan rangsangan melalui IMD, ASI tetap tidak keluar seperti yang diharapkan. Selain itu ketidaklancaran ASI dikarenakan bayi tidak melekat sempurna pada payudara ibu yang menyebabkan hisapan bayi pada puting kurang kuat untuk mengeluarkan ASI. Kondisi ini menyebabkan ASI yang keluar lebih sedikit. Selain itu, stimulasi dan rangsangan tubuh untuk memproduksi ASI juga menurun. Bayi yang melekat tidak sempurna pada payudara ibu sering disebabkan karena posisi menyusui yang tidak tepat. Produksi ASI juga berkurang atau tidak lancar karena keterbatan frekuensi dan waktu menyusui (Setyowati 2018).

Gambaran Keikutsertaan KP ibu Kelas Ibu Hamil responden dapat diperlihatkan pada table 5 berikut:

Tabel 5. Distribusi Frekuensi Keikutsertaan KP Ibu Kelompok Kasus dan Kelompok

\begin{tabular}{c|l|c|c|c|c|c|c|c}
\multirow{2}{*}{ No. } & \multirow{2}{*}{$\begin{array}{c}\text { Keikutsertaan } \\
\text { KP ibu }\end{array}$} & \multicolumn{2}{|c|}{$\begin{array}{c}\text { Kelompok } \\
\text { kasus }\end{array}$} & $\begin{array}{c}\text { Kontrol } \\
\text { Kelompok } \\
\text { kontrol }\end{array}$ & \multicolumn{4}{|l}{} \\
\cline { 3 - 7 } & & F & \% & F & \% & X & P & OR \\
\hline 1. & Ya & 59 & 69,1 & 71 & 84,5 & 6.441 & 0,008 & 2.58 \\
\hline 2. & Tidak & 25 & 30,9 & 13 & 15,5 & & & \\
\hline & Total & 84 & 100 & 84 & 100 & & &
\end{tabular}

Uji statistic menggunakan chi square

Berdasarkan tabel 5. menunjukkan bahwa kegagalan pemberian ASI eksklusif yang dialami responden yang mengikuti KP ibu 68,5\% dan yang berhasil memberikan ASI eksklusif 83,9\%. Hasil uji chi square menyimpulkan ada perbedaan kegagalan ASI eksklusif pada ibu yang ikut serta KP ibu dan tidak ikut KP ibu. Kegagalan dalam memberikan ASI eksklusif 2.58 kali lebih besar dialami oleh ibu yang tidak mengikuti KP ibu.

Penelitian ini tidak sesuai dengan penelitian sebelumnya yang menyebutkan bahwa keberhasilan pemberian ASI secara signifikan tidak berhubungan dengan keiktusertaan ibu hamil dalam kelompok pendukung ibu. Tidak adanya hubungan tersebut disebabkan karena peserta KP ibu kurang mendapatkan dukungan dan fasilitas untuk melaksanakan apa yang disarankan selama mengikuti KP ibu. Selain itu, peserta KP ibu juga kurang mendapatkan dukungan dari petugas kesehatan untuk menerapkan informasi yang diterima selama mengikuti KP ibu terutama dalam upaya memberikan ASI secara eksklusif (Septianingrum 2016).

Gambaran Pengetahuan Tentang ASI eksklusif pada kelompok kasus dan kelompok kontrol dapat diperlihatkan pada tabel 6 berikut: 
Tabel 6. Distribusi Frekuensi Pengetahuan Tentang ASI Eksklusif Kelompok Kasus dan Kelompok Kontrol

\begin{tabular}{c|l|c|c|c|c|c|c|c}
\multirow{2}{*}{ No. } & \multirow{2}{*}{$\begin{array}{c}\text { Pengetahuan } \\
\text { ibu Tentang }\end{array}$} & \multicolumn{2}{|c|}{$\begin{array}{c}\text { Kelompok } \\
\text { kasus }\end{array}$} & \multicolumn{2}{c|}{$\begin{array}{c}\text { Kelompok } \\
\text { kontrol }\end{array}$} & \multicolumn{3}{|l}{} \\
\cline { 3 - 7 } & ASI eksklusif & F & \% & F & \% & X & P & OR \\
\hline 1. & Rendah & 26 & 32,1 & 21 & 25,6 & 1.035 & 0,189 & 1.419 \\
\hline 2. & Tinggi & 58 & 67,9 & 63 & 74,4 & & & \\
\hline & Total & 84 & 100 & 84 & 100 & & &
\end{tabular}

Uji statistic menggunakan chi square

Berdasarkan tabel 6. menunjukkan bahwa kegagalan pemberian ASI eksklusif $(67,3 \%)$ dan berhasil memberikan ASI eksklusif $(73,8 \%)$ dialami oleh responden yang mempunyai pengetahuan tinggi tentang ASI eksklusif. Hasil uji chi square menyimpulkan tidak ada perbedaan kegagalan atau keberhasilan ASI eksklusif pada ibu yang mempunyai pengetahuan tinggi atau rendah tentang ASI eksklusif. Kegagalan dalam memberikan ASI eksklusif dapat dialami oleh Responden yang mempunyai pengetahuan tinggi atau rendah tentang ASI eksklusif.

Ibu menyusui yang mempunyai pengetahuan rendah tentang tujuan dan manfaat pemberian ASI eksklusif merupakan faktor penyebab kegagalan pemberian ASI eksklusif pada bayi. Kurangnya informasi yang dimiliki ibu selama hamil tentang ASI menyebabkan ibu kurang memahami pentingnya memberikan ASI secara eksklusif kepada bayinya. Pengetahuan yang rendah menyebabkan ibu sering kurang mengetahui dan memahami tata laksana laktasi yang benar seperti, pentingnya memberikan ASI, bagaimana ASI keluar, bagaimana posisi menyusui, dan perletakan bayi yang baik dan benar pada payudara ibu selama IMD (Kusumaningrum 2016). Ibu yang mempunyai pengetahuan baik $(72,8 \%)$ lebih banyak yang memberikan ASI eksklusif pada bayinya dibandingkan dengan ibu yang mempunyai pengetahuan kurang (20.6\%). Ibu yang mempunyai pengetahuan yang baik tentang ASI eksklusif mempunyai peluang 13,09 kali lebih besar untuk memberikan ASI eksklusif dibanding ibu yang memiliki pengetahuan kurang tentang ASI eksklusif (Jannah 2016).

Gambaran Dukungan Keluarga Keikutsertaan Kelas Ibu Hamil responden dapat diperlihatkan pada table 7 berikut:

Tabel 7. Distribusi Frekuensi Dukungan Keluarga Kelompok Kasus dan Kelompok Kontrol

\begin{tabular}{c|l|c|c|c|c|c|c|c}
\multirow{2}{*}{ No. } & \multirow{2}{*}{$\begin{array}{c}\text { Dukungan } \\
\text { Keluarga }\end{array}$} & \multicolumn{2}{|c|}{$\begin{array}{c}\text { Kelompok } \\
\text { kasus }\end{array}$} & \multicolumn{2}{c|}{$\begin{array}{c}\text { Kelompok } \\
\text { control }\end{array}$} & \multicolumn{2}{|c}{} \\
\cline { 3 - 6 } & & F & \% & F & \% & X & p & OR \\
\hline 1. & Tinggi & 49 & 57,2 & 53 & 62,5 & 0.625 & 0,255 & 1.289 \\
\hline 2. & Rendah & 35 & 42,8 & 32 & 37,5 & & & \\
\hline & Total & 84 & 100 & 84 & 100 & & &
\end{tabular}

Uji statistic menggunakan chi square

Berdasarkan tabel 7. menunjukkan bahwa responden yang gagal memberikan ASI eksklusif $(56,6 \%)$ dan berhasil memberikan ASI eksklusif 
(61,9\%) sebagaian besar mendapatkan dukungan keluarga yang tinggi. Hasil uji chi square menyimpulkan tidak ada perbedaan dukungan keluarga antara kelompok kasus dan kelompok kontrol dalam mengalami kegagalan ASI eksklusif. Kegagalan dalam memberikan ASI eksklusif dapat dialami oleh responden yang mempunyai dukungan keluarga rendah dan tinggi.

Hasil penelitian menyebutkan ibu yang mendapatkan dukungan keluarga yang baik lebih berhasil dalam memberikan ASI eksklusif dibandingkan dengan ibu yang mendapatkan dukungan kurang baik dari keluarga. Ibu yang mendapat dukungan keluarga memiliki peluang 7,6 kali lebih besar untuk memberikan ASI eksklusif dibandingkan dengan ibu yang tidak mendapatkan dukungan keluarga (Septiani 2017).

Gambaran Dukungan Suami responden dapat diperlihatkan pada table 8 berikut:

Tabel 8. Distribusi Frekuensi Dukungan Suami Kelompok Kasus dan Kelompok Kontrol

\begin{tabular}{|c|l|c|c|c|c|c|c|c|}
\hline No. & \multirow{2}{*}{$\begin{array}{c}\text { Dukungan } \\
\text { Suami }\end{array}$} & \multicolumn{2}{|c|}{ Kelompok kasus } & \multicolumn{2}{|c|}{$\begin{array}{c}\text { Kelompok } \\
\text { kontrol }\end{array}$} & \multicolumn{3}{c|}{ Chi square } \\
\cline { 3 - 9 } & & F & \% & F & \% & X & p & OR \\
\hline 1. & Baik & 45 & 26.8 & 60 & 35.7 & 6.472 & 0,007 & 2.283 \\
\hline 2. & Kurang & 39 & 23.2 & 24 & 14.3 & & & \\
\hline & Total & 84 & 100 & 84 & 100 & & & \\
\hline
\end{tabular}

Uji statistic menggunakan chi square

Berdasarkan tabel 8. menunjukkan bahwa responden yang gagal memberikan ASI eksklusif (26,8\%) dan berhasil memberikan ASI eksklusif $(35,7 \%)$ sebagian besar mendapatkan dukungan suami baik. Hasil uji chi square menyimpulkan ada perbedaan dukungan suami antara kelompok kasus dan kelompok kontrol dalam mengalami kegagalan ASI eksklusif. Responden yang mendapatkan dukungan suami kurang memiliki peluang 2.273 lebih besar untuk mengalami kegagalan dalam memberikan ASI eksklusif dibandingkan responden yang mendapatkan dukungan suami yang baik.

Kehadiran dan perhatian suami di samping ibu menyusui memberikan motivasi yang besar kepada ibu menyusui untuk berusaha semaksimal mungkin memberikan ASI secara eksklusif kepada bayinya. Ibu menyusui sangat mengharapkan suami mengingatkan ibu untuk selalu memberikan ASI saja meskipun sebenarnya ibu tahu bahwa memberikan ASI eksklusif penting untuk tumbuh kembang bayi secara optimal. Kondisi ibu yang sehat dan suasana yang menyenangkan akan meningkatkan kestabilan fisik ibu untuk menunjang produksi ASI lebih baik (Roesli 2015). Penelitian Ode (2011) menyebutkan ada hubungan dukungan suami dengan keberhasilan pemberia ASI eksklusif (Saleh 2011). Dukungan suami yang rendah menyebabkan kegagalan pemberian ASI eksklusif (Handayani 2018). 


\section{Analisis multivariat}

Analisis multivariat dilakukan menggunakan uji regresi logistic terhadap variable-variabel yang diteliti. Hasil uji multivariat diperlihatkan sebagai berikut:

Tabel 9. Hasil Uji Regresi Logistic

\begin{tabular}{|c|c|c|c|c|}
\hline \multirow[t]{2}{*}{ Variable } & \multirow[b]{2}{*}{ Sig. } & \multirow[b]{2}{*}{$\operatorname{Exp}(B)$} & \multicolumn{2}{|c|}{ 95\% C.I.for $\operatorname{EXP}(B)$} \\
\hline & & & Lower & Upper \\
\hline Kelas Ibu Hamil & 0.023 & 2.78 & 1.15 & 6.70 \\
\hline Kelompok Pendukung ibu & 0.009 & 2.98 & 1.31 & 6.75 \\
\hline Dukungan suami & 0.008 & 2.53 & 1.26 & 5.04 \\
\hline
\end{tabular}

Adjusted $R^{2}: 0,197$

Tabel 9. menunjukkan bahwa setelah dikontrol dapat diketahui bahwa faktor keikutsertaan $\mathrm{KIH}$, keikutsertaan $\mathrm{KP}$ ibu, dan dukungan suami mempunyai pengaruh sebesar 19,7\% terhadap kegagalan ASI eksklusif. Responden yang memiliki peluang mengalami kegagalan ASI eksklusif adalah tidak mengikuti $\mathrm{KIH}$ (2,78 kali lebih besar), tidak mengikuti KP ibu (2,98 kali lebih besar) dan tidak mendapatkan dukungan suami dengan baik (2,53 kali lebih besar). Pemberian ASI eksklusif lebih banyak dilakukan oleh ibu yang mengikuti kelas ibu hamil dan didukung suami (Pertiwi 2017) (Kurniawan 2013). Keikutsertaan dalam kegiatan KP ibu dapat meningkatkan pengetahuan dan praktik pemberian ASI eksklusif (Indonesia 2011).

\section{SIMPULAN}

Berdasarkan hasil penelitian dan pembahasan dapat diambil kesimpulan bahwa secara statistik tidak ada perbedaan lama pendidikan, pekerjaan, cara persalinan dan perbedaan berat badan lahir antara kelompok kasus dan kelompok kontrol untuk mengalami kegagalan ASI eksklusif. Ada perbedaan urutan anak dan penghasilan keluarga antara kelompok kasus dan kelompok kontrol untuk mengalami kegagalan ASI eksklusif. Variable yang bukan merupakan faktor risiko kegagalan ASI eksklusif adalah pelaksanaan IMD, pengetahuan tentang ASI eksklusif dan dukungan keluarga. Factor risiko kegagalan ASI eksklusif adalah keikutsertaan Kelas Ibu Hamil (OR 2.35), keikutsertaan KP ibu (OR 2.58), dan dukungan suami (OR 2,273)

\section{SARAN}

Bagi peneliti selanjutnya agar mengembangkan hasil penelitian ini untuk mengetahui variable mana yang paling mempengaruhi kegagalan pemberian ASI eksklusif.

\section{DAFTAR PUSTAKA}

Bantul, Dinkes. 2020. Narasi Profil Kesehatan Kabupaten Bantul Tahun 2020. Yogyakarta: Dinkes Bantul. 
BKKBN. 2011. Kamus Istilah Kependudukan Dan Keluarga Berencana. Jakarta: BKKBN.

Dinkes, DIY. 2017. Profil Kesehatan Provinsi Di Yogyakarta Tahun 2017. Yogyakarta: Dinas Kesehatan.

Dwinanda, N. 2018. "Factors Affecting Exclusive Breastfeeding in Term Infants." Paediatrica Indonesiana 58(1):25-35.

Handayani, Sri dan Putri Halimu Husna. 2018. Faktor Determinan Rendahnya Pemberian ASI Eksklusif (Studi Deskriptif Di Desa Balepanjang Kecamatan Baturetno). Wonogiri.

Ida. 2012. Faktor-Faktor Yang Berhubungan Dengan Pemberian ASI Eksklusif 6 Bulan Di Wilayah Kerja Puskesmas Kemiri Muka Kota Depok Tahun 2011. Jakarta.

Indonesia, Mercy Corps. 2011. Panduan Pelatihan Pembina Motivator Kelompok Pendukung Ibu Jakarta. Jakarta: Merci Corps.

Jannah, Ana Mahillatul. 2016. "Faktor - Faktor Yang Berhubungan Dengan Perilaku Pemberian ASI Eksklusif Pada Bayi Usia 6 - 12 Bulan Di Kelurahan Gerem Wilayah Kerja Puskesmas Grogol Kota Cilegon Tahun 2015." UNIVERSITAS ISLAM NEGERI SYARIF HIDAYATULLAH JAKARTA.

Kemenkes. 2018. Profil Kesehatan Indonesia 2018. Jakarta: Kemenkes.

Kurniawan, Bayu. 2013. "Determinan Keberhasilan Pemberian Air Susu Ibu Eksklusif.” Jurnal Kedokteran Brawijaya 7(4):236-40.

Kurniawati\&Rachmat. 2014. Faktor Determinan Yang Mempengaruhi Kegagalan Pemberian ASI Eksklusif Pada Bayi Usia 0-6 Bulan Di Kelurahan Mulyarejo Wilayah Kerja Puskesmas Mulyarejp Surabaya. Surabaya: Unair.

Kusumaningrum, Tyas. 2016. "Gambaran Faktor-Faktor Ibu Yang Tidak Memberikan Asi Eksklusif Di Desacepokosawit Kabupaten Boyolali." Fakultas Ilmu Kesehatan Universitas Muhammadiyah Surakarta.

Pertiwi, R. 2017. "Hubungan Keikutsertaan Kelas Ibu Hamil Dan Dukungan Sosial Keluarga Dengan Perilaku Pemberian ASI Eksklusif Di Wilayah Kerja Puskesmas Kedungmundu." Jurnal Kesehatan Masyarakat (EJournal) 5(4).

Roesli, Utami. 2015. Mengenal Asi Eksklusif. Jakarta: Trubus Agriwidya.

Saleh, La Ode Amal. 2011. "Faktor-Faktor Yang Menghambat Praktik ASI Eksklusif Pada Bayi Usia 0-6 Bulan.” Universitas Diponegoro. Semarang.

Septiani, H. 2017. "Faktor-Faktor Yang Berhubungan Dengan Pemberian ASI 
Eksklusif Oleh Ibu Menyusui Yang Bekerja Sebagai Tenaga Kesehatan.” Jurnal Ilmu Kesehatan 2(2):159-74.

Septianingrum, A. 2016. "Hubungan Peran Kelompok Pendukung Ibu Dengan Keberhasilan Pemberian Asi Eksklusif Di Wilayah Kerja Puskesmas Gambirsari Surakarta." Fakultas Ilmu Kesehatan Universitas Muhammadiyah Surakarta.

Setianingsih, Haryono dan. 2014. Manfaat ASI Eksklusif Untuk Buah Hati Anda. Yogyakarta: Gosyen Publishing.

Setyowati, Anis. 2018. "Hubungan Inisiasi Menyusui Dini Dengan ASI Selama 6 Bulan Pertama." Jurnal Manajemen Kesehatan Yayasan RS.Dr.Soetomo 4(1):30-37.

Suwardiman. 2015. Determinan Pemberian ASI Eksklusif Di Wilayah Kerja Puskesmas Jatiuwung Kota Tangerang Tahun 2014. Jakarta.

Wadud, MA. 2012. Hubungan Umur Ibu Dan Paritas Dengan Pemberian ASI Eksklusif Pada Bayi Berusia 0-6 Bulan Di Puskesmas Pembina Palembang Tahun 2013. Palembang. 